\title{
PEMBERDAYAAN PEREMPUAN MELALUI PROGRAM PENDIDIKAN KEWIRAUSAHAAN KREATIKF TERPADU UNTUK PEREMPUAN, ANAK, DAN KELUARGA OLEH ORGANISASI WORLD MUSLIMAH FONDATION DI KAMPUNG MUKA, JAKARTA UTARA
}

\author{
Oleh: \\ Gevia Nur Isna Deraputri,. R. Nunung Nurwati, \& Risna Resnawaty \\ E-mail : gderaputri@gmail.com
}

\begin{abstract}
Abstak Penelitian ini mendeskipsikan program pemberdayaan perempuan yang dilakukan oleh Organisasi perempuan muslimah, World Muslimah Fondation melalui kegiatan pendidikan Kewirausahaan Kreatif Terpadu untuk Perempuan, Anak, dan Keluarga yang dilakukan di Pemukiman Kumuh Kampung Muka Jakarta Utara dengan target sasaran pemberdayaannya adalah ibu-ibu dari golongan menengan kebawah. Penelitian ini menggunakan pendekatan kualitatif dan jenis penelitian deskriptif. Penelitian ini menggambarkan mengenai proses dari pemberdayaan kepada perempuan melalui tahapan pemberdayaan masyarakat dan juga pemberdayaan yang terintergrasi. Program pemberdayaan perempuan melalui pendidikan kewirausahaan kreatif ini adalah salah satu cara untuk menjadikan ibu-ibu di daerah kampung muka lebih mandiri, mempunyai keterampilan, dan mampu mengembangkan dirinya, keluarganya, serta orang-orang yang ada di sekitarnya.
\end{abstract}

Kata Kunci :

Pemberdayaan, Perempuan, Pendidikan Kewirausahaan kreatif

Abstract This research desribe about women empowerment by World Muslimah Fondation through creative entrepreneurship for woman, children, and family in Kampung Muka, North Jakarta with middle-low wife group as a target. The research use a qualitative methode and descriptive interpretive. The research show the process of woman empowerment had been carried out well based on the community empowerment and integrated empowerment. Woman empowerment program through creative entrepreneurship is a way change their (woman/ house wife) lives to a better condition which they can empower them self, their family and community.

Key Word:

Empowerment, Woman, creative entrepreneurship

\section{PENDAHULUAN}

Kemiskinan merupakan masalah yang sangat mendasar bagi negara Indonesia. Kemiskinan seperti tidak terlepas dari bahasan masalah-masalah lainnya. Kemiskinan di Indonesia, khususnya di kota Jakarta,seperti tidak pernah habis dan tidak pernah berakhir. Berbagai penanganan untuk mengurangi jumlah masyarakat miskin sudah di lakukan, pencegahan terus di lakukan oleh pemerintah pusat dan juga pemerintah daerah hanya saja kemiskinan masih merajalela. Dapat dilihat 
dari masih banyaknya pemukiman pemukiman kumuh di kota Jakarta. Menurut data jumlah penduduk miskinya sampai dengan Maret 2015 tercatat 363,2 ribu dengan tingkat kemiskinan 3,69\% (data Badan Pusat Statistik DKI Jakarta), dan menurut data PBB, 1/3 dari penduduk di dunia hidup dibawah garis kemiskinan dan sekitar $70 \%$ dari mereka adalah perempuan (dalam Cahyono, 2005, hal. 1). Jumlah penduduk perempuan di Jakarta menurut data BPS, penduduk di Kota Jakarta sebanyak 9.607.787 yang bertempat tinggal di perkotaan. $50,70 \%$ nya adalah jumlah laki laki dan 49,30\% nya adalah jumlah perempuan. Dari data tersebut dapat disimpulkan bahwa pengembangan dan pengembangan perempuan harus segera dilakukan untuk menekan angka kemiskinan di Jakarta. Pada kehidupan masyarakat di Indonesia, Kaum perempuan masih saja di anggap sebagai sub-koordinat dari kaum laki-laki, tidak boleh melebihi lakilaki dalam berbagai hal, dan di anggap sebagai pengurus rumah tangga. Mungkin ini merupakan salah satu akibat dari adanya sistem partriarki yang di anut oleh sebagian masyarakat Indonesia yang menjadikan posisi perempuan masih saja ada di bawah laki-laki. serta pemerintah yang kurang memandang perempuan dalam penuntasan kemiskinan dan kurang memperhatikan posisi perempuan dalam pembuatan kebijakan-kebijakan.

Ada dua pendekatan untuk melihat kemiskinan yang petama adalah pendekatan absolut dan relatif. Pendekatan absolut menyatakan bahwa sejumlah kepemilikan barang dan jasa adalah mutlak penting bagi kesejahteraan individu dan keluarga. Barang siapa yang jumlah kepemilikan barang dan jasanya dibawah jumlah minimum, maka dinilai sebagai orang miskin. Permasalahannya adalah tidak ada persetujuan terkait jumlah minimum yang ditentukan untuk dapat dikatakan termasuk golongan miskin, karena bergantung pada pendapatan, angka, dan presentase dari populasi yang dinamis dan sewaktu-waktu dapat berubah mengikuti karakteristik yang didefnisikan sebagai prang miskin, berbeda dengan pendekatan relatif yang menyatakan bahawa orang dapat dikataka miskin jika pendapatannya dibawah dari rata-rata dari populasi yang ada. pendefinisian kemiskinan sebagai pendekatan yang relatif lebih menekankan kepada ketimpangan pendapatan, secara ideal melalui pendekatan ini, kemiskinan didefinisikan tidak hanya dengan angka, namun juga dengan bagaiman kondisi kehidupan mereka. Golongan yang termasuk ke dalam kelompok miskin biasanya perempuan yang menjadi kepala keluarga, anak-anak, manusia lanjut usia, manusia dengan tingkat pendidikan yang rendah dan pengangguran. Beberapa penelitian menyebutkan pula bahwa orang miskin memiliki nilai-nilai dan peilaku yang mengakar dan membentuk kebudayaan kemiskinan (dalam Zastrow, 2004, hal. 134136).

Penyebab kemiskinan yang terjadi di indonesia adalah minimnya masyarakat yang mengenyam pendidikan dan hanya pendidikan dasar. Kebanyakan dari Mereka hidup hanya untuk mencari uang agar mereka dapat memenuhi kebutuhan hidupnya dengan mengandalkan lapangan kerja yang ada. Pemberdayaan merupakan salah satu cara untuk menangani masalah kemiskinan yang ada di Indonesia. Pemberdayaan masyarakat sendiri merupakan konsep awal bagi pekerja sosial. Pemberdayaan masyarakat adalah cara bagaimana pekerja sosial Pemberdayaan merupakan sebuah konsep dimana individu atau kelompok akan dapat menentukan sendiri penyelesaian masalah untuk dirinya sendiri, mendorong mereka mengembangkan potensi yang ada dalam dirinya. Juga mereka akan dapat memiliki kesadaran dan kekuasaan penuh atas dirinya sendiri. dapat menjadikan individu ataupun komunitas dapat berdaya, dapat mengembangkan potensi yang ada dalam diri mereka, dan mereka dapat mampu menyelesaikan permasalahan secara mandiri dalam upaya menjadikan dirinya sejahtera.

Konsep pemberdayaan ini juga di bahas oleh Shardlow (1998), pemberdayaan pada intinya membahas bagaimana individu, kelompok 
atau komunitas berusaha mengontrol kehidupan mereka sendiri dan mengusahakan untuk membentuk masa depan sesuai dengan keinginan mereka (dalam Adi, 2008, hal.78). dalam Adi (2012; 213) Hogan menjelaskan bahwa dalam konteks kesejahteraan sosial pemberdayaan terkait dengan upaya meningkatkan taraf hidup masyarakat dari suatu tingkatan ke tingkatan yang lebih baik. Tentunya dengan mengkaji faktor-faktor yang menyebabkan suatu komunitas menjadi kurang beraya (depowerment).

Pemberdayaan merupakan proses, yang dalam artian proses berarti sesuatu yang bertahap dan terus berjalan. Pemberdayaan merupakan proses yang berkesinambungan. Hogan (2003) yang mengutip pandangan Rotter (1966), Selignan (1975), Hopson dan Scally (1995) yang melihat proses emberdayaan individu sebagai suatu proses yang relatif terus berjalan sepanajang usia manusia yang diperoleh dari pengalaman indvidu tersebut, bukannya suatu proses yang berhenti pada suatu masa saja (dalam Adi, 2008, hal 83-84).

Pemberdayaan sosial kepada perempuan untuk menjadikan perempuan yang lebih berdaya dan dapat keluar dari lingkaran kemiskinan adalah salah satu cara untuk menuntaskan masalah kemiskinan yang ada di kota Jakarta. Pemberdayaan tersebut dapat dilakukan melalui pengembangan masyarakat atau lebih dikenal dengan Community Development yang merupakan pengembangan masayarakat secara mudah dimengerti dengan cara melibatkan masyarakat didalam proses pemberdayaan tersebut secara aktif.

Community Develompent ini merupakan salah satu upaya agar terciptanya kapasitas masyarakat yang lebih baik yang agar mereka dapat memecahkan berbagai persoalan yang timbul terkait untuk peningkatan kualitas hidup dan juga kesejahteraannya. Pemberdayaan menurut Ife (1995: 182 dalam buku "community development: creating community alternatives-vision, analysis and practice") memberikan batasan pemberdayaan sebagai upaya penyediaan kepada orang-orang atas sumber, kesempatan, pengetahuan, dan keterampilan untuk meningkatkan kemampuan mereka menentukan masa depannya dan untuk berpartisipasi di dalam dan mempengaruhi kehidupan komunitas mereka.

Perlu adanya pemberdayaan yang dilakukan untuk perempuan melihat data yang didapat bahwa lebih dari setengah penduduk miskin adalah perempuan. Perempuan merupakan anggota masyarakat yang mempunyai peran penting dalam sebuah keluarga, dalam masyarakat, dan juga dalam negara. Salah satu peran perempuan yang paling penting dimulai dari sebuah keluarga, perempuan mempunyai tugas salah satunya adalah membantu anak mendapatkan haknya yaitu mendapatkan rasa aman dan kasih sayang. Selain itu tugas perempuan dalam keluarga adalah mengajarkan anak nilai-nilai baik yang diterapkan dalam keluarga maupun dalam masyarakat, mendidik anak agar si anak menjadi pintar dan mampu berkembang. Dalam keluarga, perempuan juga berperan sebagai istri bagi suaminya. Istri mempunyai peran yang berbeda dengan seorang ibu. Seorang istri haruslah dapat mendukung suaminya, menjadi teman baik untuk suaminya, dan juga memberikan semangat agar suaminya mampu menjalankan perannya dengan baik, baik itu di dunia pekerjaan, keluarga, maupun dalam masyarakat. Seorang Istri juga menjadi pendorong untuk suaminya dalam bertindak. Haruslah seorang istri memberikan dorongan yang positif untuk suaminya agar suaminya dapat menjadi seorang yang positif, tidak melenceng kehidupannya dan harus dapat menjaga nama baik suaminya juga menjaga aib-aib keluarganya. Dalam kehidupan bermasyarakat, perempuan mempunyai kedudukan yang sama dengan laki-laki yaitu sebagai anggota atau bagian dari masyarakat yang memiliki hak dan kewajiban sebagai manusia. Namun Perempuan mempunyai peranan yang besar dalam pembangunan masyarakat. Kesetaraan gender adalah salah satu alasan bagi masyarakat luas untuk memperhitungkan posisi perempuan di berbagai bidang kehidupan seperti pada bidang 
ekonomi, politik, dan juga bidang bidang lainnya. Posisi perempuan dalam masyarakat hampir setara dengan posisi laki-laki, dimana perempuan juga diberikan kewenangan untuk dapat mendapatkan pendidikan setinggitingginya, kewenangan untuk berpendapat, bekerja sesuai dengan bidang yang diinginkan. Karena itu, menjadi perempuan haruslah cerdas dan bisa berbagai macam hal.

Organisasi World Muslimah Fondation telah menerapkan pemberdayaan masyarakat yang di khususkan untuk perempuan. Pemberdayaan tersebut merupakan salah satu dari kegiatan dan program yang dibuat untuk mengangkat derajat perempuan terutama perempuan muslim. Program pemberdayaan perempuan ini diadakan di wilayah kumuh Kampung Muka di daeah Jakarta Utara. Pemberdayaan yang dilakukan merupakan salah satu cara untuk mengurangi angka kemiskinan. Program pemberdayaan yang di terapkan adalah Pendidikan kewirausahaan kreatif. Pemberdayaan melalui kegiatan pendidikan kewirausahaan kreatif dipilih karena melihat lokasi tempat dilakukan kegiatan pemberdayaan sangat mendukung untuk keberlangsungan pengembangan diri dari perempuan yang diberdayakan.

Pemberdayaan perempuan dilakukan di daerah kampung muka karena melihat kondisi di Kampung muka yang sudah mengkhawatirkan. Banyaknya masalahmasalah yang terjadi di daerah kumuh ini. masalah yang paling menonjol adalah degradasi moral pada anak-anak dibawah umur. Penyebaran film porno dan narkoba dikalangan anak-anak sudah bukan menjadi hal yang tabuh ini terjadi akibat berbagai macam hal dianntaranya padatnya manusia di daerah pemukiman, tidak adanya pengawasan dari orang tua mereka yang berada dirumah, serta kurangnya pendidikan pada orangtua sehingga mereka tidak tahu cara mendidik anak yang benar, dan masalah ekonomi.

Fokus program pemberdayaan organisasi WMF ini adalah memberdayakan ibu rumah tangga di daerah kampung muka karena menaggap bahwa ibu merupakan peran penting dalam terbentuknya suatu keluarga yang sejahtera. Tidak hanya ibu-ibu, program ini juga di tujukan untuk anak-anak perempuan. Mereka dilatih bernari dan diberikan motivasimotivasi sehingga mereka mempunyai rasa kepercayadirian pada dirinya. Yang menarik adalah organisasi ini melakukan integrated community development, tujuannya adalah untuk menghasilkan kemandirian yang berkelanjutan pada ibu-ibu yang diberdayakan agar mereka dapat menyelesaikan masalah sosial yang ada di lingkungan mereka terkait kesejahteraannya.

Program ini merupakan rangkaian dari proses pemberdayaan yang masih berlangsung sampai dengan sekarang. Ada lima tahap pemberdayaan yang dilakukan oleh WMF, yang pertama adalah proses Assesment, menganalisis keadaan kampung muka melalui analisis Stregth, Weakness, Opportunity, Threat yang tedapat di kampung muka dan juga melalui Financial Check dan Personality check. Selanjutnya adalah Capacity Bulding, yang dibangun adalah kompetensi dan karakter para ibu-ibu yang mengikuti program pemberdayaan. Tahap selanjutnya adalah Working group, Branding and Promotion, dan yang terakhir adalah Market Access.

\section{PEMBAHASAN}

Berangkat dari permasalahan yang terjadi di kalangan masyarakat Indonesia, lebih tepatnya di Ibu Kota. Masalah ini sudah muncul sejak jaman dahulu dan masih bertahan hingga hari ini, Masalah Kemiskinan. Lingkaran kemiskinan di Jakarta sudah semakin meluas. Terlihat dari banyaknya pemukiman-pemukiman kumuh di beberapa sudut kota ini. Kemiskinan sudah menjadi permasalahan yang selalu berusaha dipecahkan oleh pemerintah-pemerintah negara dan daerah namun hingga saat ini belum saja ditemukan penyelesaian yang tepat untuk masalah ini. masyarakat miskin di negara berkembang menurut PBB $70 \%$ dari 
masyarakat miskin tersebut adalah Wanita. Melihat fakta yang ada dilapangan dan data yang ditemukan, bisa saya tarik kesimpulan bahwa kemiskinan identik dengan wanita. Kenapa wanita ? wanita seharusnya mempunyai pernanan yang penting bagi masyarakat bahkan negara.

Kebanyakan dari wanita yang bertempat tinggal di daerah kumuh memilih untuk bekerja dibandingkan mengurus rumah tangga dirumah. Mereka bekerja untuk mencukupi kebutuhan hidup mereka yang paspasan. Wanita di daerah kumuh juga identik dengan pendidikan yang kurang, banyak dari warga miskin hanya lulusan sekolah dasar.

Dengan adanya kondisi wanita yang miskin dan mempunyai pendidikan kurang dan juga wanita yang hidupnya dilingkungan kumuh dan ia bekerja menyebabkan timbulnya beberapa masalah dari kondisi tersebut masalah yang paling fatal adalah anak-anak mereka. Ketidak tahuan dan juga akses yang kurang memadai untuk menunda kehamilan menyebabkan kebanyakan warga di daerah kumuh memiliki anak yang banyak. Karena kondisi ekonomi yang kurang, mereka akhirnya harus bekerja dan membiarkan anakanak mereka bermain bebas sepanjang hari tanpa adanya kontrol orang tua, disinilah penyebaran hal-hal negatif seperti pornografi dan pemakaian narkoba berkembang. Tidak hanya itu, kondisi ekonomi yang kurang serta ditambah dengan kondisi anak yang banyak menyebabkan anak-anak di daerah kumuh putus sekolah dan memilih untuk bekerja membantu perekonomian orang tua mereka. Dan masalah-masalah lain akan bermunculan dari tidak adanya peran wanita dengan baik dalam keluarga.

Wanita mengemban peran penting dalam keluarga. Wanita menciptakan kehidupan. Wanita seharusnya adalah pondasi bagi sebuah keluarga bahkan masyarakat. Wanita yang pintar mampu menghasilkan keturunan yang berkualitas juga, wanita yang memiliki pengetahuan yang luas, mampu memberikan dukungan bagi suaminya dan mampu berkontribusi didalam kehidupan bermasyarakat. Namun pada kenyataannya, masih saja ada wanita masih terhalang oleh nilai-nilai budaya, terhalang oleh peran yang di kontruksikan masyarakat, dan terhalang oleh nilai leluhur.

Berangkat dari kondisi tersebut, haruslah wanita yang masih ada di keadaan miskin tersebut mendapatkan ilmu atau sesuatu yang lebih, haruslah mereka di berdayakan agar mereka dapat keluar dari lingkaran kemiskinan dan juga dapat menciptakan generasi dan keluarga yang baik. Pemberdayaan sangat perlu dilakukan. Pemberdayaan dalam Adi $(2012 ; 213)$ Hogan menjelaskan bahwa dalam konteks kesejahteraan sosial pemberdayaan terkait dengan upaya meningkatkan taraf hidup masyarakat dari suatu tingkatan ke tingkatan yang lebih baik. Tentunya dengan mengkaji faktor-faktor yang menyebabkan suatu komunitas menjadi kurang beraya (depowerment).

Kesadaran akan pentingnya pemberdayaan pada wanita adalah salah satu alasan yang mendasari organisasi yang memang fokus kepada wanita muslim di dunia, World Muslimah Fondation, melakukan suatu proses pemberdayaan. Karena pemberdayaan merupakan sebuah proses, organisasi WMF ini mempunyai beberapa tahapan untuk pemberdayaannya dan mempunyai tujuan yang jelas dengan waktu yang telah di tentukan. Salah satu tujuan pemberdayaan yang dilakukan organisasi ini adalah menaikan taraf hidup wanita yang berada di pemukiman kumuh terbesar di Asia. Pemberdayaan yang dilakukan tidak hanya sekedar program yang telah disusun oleh organisasi ini, pemberdayaan yang dilakukan dilaksanakan dengan berkesinambungan. juga, target dari pemberdayaan sangat dilibatkan dalam pemberdayaan ini.

Penerapan pemberdayaan ini menggunakan metode community development atau dikenal dengan istilah pengembangan komunitas/masyarakat dengan pengembangan metode menjadi integrated commynity development. Diharapkan dengan 
metode tersebut wanita di daerah kumuh tersebut dapat mengembangkan dirinya dan potensi yang ada didalam dirinya, dapat memberdayakan dirinya dan merubah nasib keluarganya, dapat bekerjasama dengan orang disekitarnya, dapat menjadi pengaruh yang baik bagi lingkungannya.

Ada lima tahap pemberdayaan yang dilakukan oleh WMF, yang pertama adalah proses Assesment, menganalisis keadaan kampung muka melalui analisis Stregth, Weakness, Opportunity, Threat yang tedapat di kampung muka dan juga melalui Financial Check dan Personality check. Selanjutnya adalah Capacity Bulding, yang dibangun adalah kompetensi dan karakter para ibu-ibu yang mengikuti program pemberdayaan. Tahap selanjutnya adalah Working group, Branding and Promotion, dan yang terakhir adalah Market Access.

Kampung muka merupakan wilayah kumuh yang dipilih untuk menjadi tempat dimana dilakukannya pemberdayaan. Pemilihan tempat kumuh ini oleh Organisasi WMF dipilih melalui analisis beberapa wilayah kumuh sebelumnya. menganalisis menggunakan analisis SWOT untuk mengetahui urgensi masalah yang ada di beberapa lingkungan kumuh tersebut. setelah itu, Dalam pelaksanaan pemberdayaannya, yang pertama dilakukan oleh organisasi ini adalah pembahasan mengenai masalah yang ada. pembahasan dan penentuan masalah dilakukan bersama sama oleh masyarakat kampung muka dengan menggunakan cara FGD atau Focus Group Discussion.

Setelah masalah ditemukan, pemecahan masalah juga didiskusikan terlebih dahulu lalu setelah itu agar pemberdayaan berjalan sesuai tujuan yang diharapkan dan berkesinambungan, peserta pemberdayaan melalui beberapa seleksi. Yang menjadi penilaian adalah data diri, sikap dan karakter diri, data penghasilan dan pengeluaran bulanan, serta status pernikahan dan data keluarga. Setelah itu barulah dipilih 21 orang yang akan diberdayakan. Secara umum kaum ibu di Kampung Muka telah banyak memberikan kontribusi kepada keluarga mereka walaupun melalui kegiatan bekerja sebagai buruh cuci, penjual eskrim, penjaga toko, berjualan di warung dan atau menjadi penjahit vermak baju.

\section{PENUTUP}

Jenis pelatihan pendidikan kewitausahaan kreatif yang dikembangkan untuk 21 peserta pemberdayaan adalah mejahit, sulam pita, sulam payet, membatik, patch work, dan pembuatan aksesoris. 21 orang tersebut di bagi kedalam masing-masing jenis pendidikan tersebut. kegiatan pendidikan kewirausahaan kreatif tersebut tidak dilakukan di Kampung Muka. Organisasi WMF menyediakan akses yang mendukung mereka untuk belajar dengan baik. Mereka diberikan ruang belajar yang memang mendukung mereka untuk belajar, mereka diberikan beberapa akses untuk mempermudah mereka seperti kendaraan selama latihan untuk pergi dan pulang, bagi mereka yang mempunyai anak kecil, mereka diberikan pengasuh anak selama mereka ada di tempat pendidikan agar anak-anak mereka tidak terbengkalai sehingga mereka bisa fokus untuk pendidikan kewirausahaan mereka. mereka juga diberikan makanan selama proses berlangsung. Tidak hanya kaum ibu, anak anak perempuan juga diberikan kegiatan yang dapat mengasah kemampuan mereka. Mereka diajarkan tari-tari tradisional seperti tari saman dan tarian islami.

Diharapkan dengan adanya pembagian pendidikan kewirausahaan adanya keadaan saling. Mereka akan saling membutuhkan untuk membuat sebuah usaha/produk mereka sendiri sehingga tidak hanya satu orang yang bekerja dan mempunyai ilmu yang banyak. Semua dapat membagi ilmu kepada ibu-ibu yang lain. Pelatihan tersebut sudah menghasilkan beberapa produk yang dihasilkan oleh mereka sendiri. Produk tersebut salah satunya digunakan untuk acara internasional World Muslimah Beauty yang diadakan oleh WMF yang diikuti oleh beberapa peserta dari berbagai negara. 
Ucapan terimakasih

Terimakasih penulis ucapkan kepada Allah SWT atas nikmatnya. Juga kepada orang tua, dan teman-teman yang selalu mendukung da memberikan inspirasi. Juga tak lupa kepada organisasi World Muslimah Fondation, Ibu Eka Shanty selaku CEO dari organisasi, Warga kampung Muka Bapak Salim dan Ibu Yanti juga kepada dosen dosen dari prodi KS Fisip UNPAD yang telah membimbing penulis.

\section{Daftar Pustaka}

Adi, Isbandi Rukminto. 2012 (Edisi Revisi). Intervensi Komunitas: Pengembangan Masyarakat ssebagai Upaya Pemberdayaan Masyarakat. Jakarta: PT RajaGrafindo Persada

Bungin Burhan. 2011. Penelitian Kualitatif. Jakarta: KENCANA
Cahyono, Imam. 2005. "Wajah Kemiskinan, Wajah Perempuan". Jurnal Perempuan (untuk pencerahan dan kesetaraan): Mengurai Kemiskinan, Dimana Perempuan ?. Jakarta: Yayasan Jurnal Perempuan jurnal

Herdiansyah, Haris. 2010. Metodologi

Penelitian Kualitatif. Jakarta:

Salemba Humanika

Sugiono. 2012. Metode Penelitian Kualitatif Kuantitatif dan R\&D.

Bandung: Alfabeta Bandung

Wibhawa, Budhi, DKK. 2010. Dasar-dasar Pekerjaan Sosial. Bandung: Widya Padjadjaran

Zastrow, Charles. (2004). Introduction to Social Work and Social Welfare. Eight Editioon. Belmont, CA : Brooks/Cole-Thomson Learning. www.bps.go 